\title{
Multivariate factor analysis of milk fatty acid composition in relation to the somatic cell count of single udder quarters
}

\author{
L. Turini, ${ }^{1,2 *} \odot$ G. Conte, ${ }^{1,3 *} \dagger \odot \odot$ F. Bonelli, ${ }^{1,2} \odot$ A. Serra, ${ }^{1,3} \odot$ M. Sgorbini, ${ }^{1,2} \odot$ and M. Mele ${ }^{1,3} \odot$ \\ ${ }^{1}$ Centro di Ricerche Agro-ambientali "E. Avanzi," University of Pisa, Via Vecchia di Marina, 6, 56122 San Piero a Grado (PI), Italy \\ 2Dipartimento di Scienze Veterinarie, Via Livornese Lato Monte, University of Pisa, San Piero a Grado, 56122 Pisa, Italy \\ ${ }^{3}$ Dipartimento di Scienze Agrarie, Alimentari, Agro-ambientali, University of Pisa, Via del Borghetto, 80, 56124 Pisa, Italy
}

\begin{abstract}
The present study investigated whether the fatty acid composition of milk changes in relation to an increase in the milk somatic cell count (SCC) of separate udder quarters. We investigated the potential of multivariate factor analysis to extract metabolic evidence from data on the quantity and quality of milk of quarters characterized by different SCC levels. We collected data from individual milk samples taken from single quarters of 49 Italian Holstein cows from the same dairy farm. Factor analysis was carried out on 64 individual fatty acids. In line with a previous study on multivariate factor analysis, a variable was considered to be associated with a specific factor if the absolute value of its correlation with the factor was $\geq 0.60$. Seven factors were extracted that explained the following groups of fatty acids or functions: de novo synthesis, energy balance, uptake of dietary fatty acids, biohydrogenation, short-chain fatty acids, very long chain fatty acids, and odd- and branched-chain fatty acids. An ANOVA of factor scores highlighted the significant effects of the SCC level on de novo fatty acids and biohydrogenation. The de novo fatty acid factor decreased significantly with a high level of SCC, from just 10,000 cells/mL, whereas the biohydrogenation factor showed a significantly higher level in quarters with SCC levels greater than 400,000 cells $/ \mathrm{mL}$. This statistical approach enabled us to reduce the number of variables to a few latent factors with biological significance and to represent groups of fatty acids with a common origin and function. Multivariate factor analysis could therefore be key to studying the influence of SCC on the lipid metabolism of single quarters. This approach also demonstrated the metabolic differences between quarters of the same animal showing a different level of SCC.
\end{abstract}

Received November 18, 2019

Accepted April 6, 2020.

*These authors contributed equally to this work.

†Corresponding author: giuseppe.conte@unipi.it
Key words: udder quarter, factor analysis, fatty acid, somatic cell count

\section{INTRODUCTION}

Milk composition is affected by several factors such as individual genetic merit, breed, age, mammary gland health, lactation stage, feeding regimen, and season (Dobranié et al., 2008). Mastitis is one of the costliest diseases in dairy production, resulting in great economic losses in the dairy industry as a consequence of reduced milk yield and quality, increased costs of milk production, reductions in casein, fat, and lactose, and increased enzymatic activity (Halasa et al., 2007; Cunha et al., 2008; Forsbäck et al., 2009). Mastitis is the consequence of mammary gland inflammation in response to infective microorganisms (Santos et al., 2003), and it is classified as clinical if symptoms of mammary dysfunction and defective milk are evident, or subclinical if no clinical signs are visible. Subclinical mastitis is the most challenging form, because it is nonsymptomatic and thus the milk quality may worsen as a consequence of the inclusion of milk high in SCC in the bulk tank (Leitner et al., 2008). On the contrary, milk from udders with clinical symptoms of mastitis is commonly discarded without affecting the overall quality of bulk milk.

A commonly used nonspecific marker for definition of mastitis is milk SCC (Vangroenweghe et al., 2002; Leitner et al., 2008; Zecconi et al., 2019). It is well known that milk from a healthy udder contains less than 100,000 somatic cells $/ \mathrm{mL}$. However, there is a wide individual variation, and healthy mammary gland values may vary from 10,000 to $10,000,000$ cells $/ \mathrm{mL}$ (Jensen et al., 1995; Hamann, 2002).

The SCC levels of single udder quarters are usually not interrelated because the 4 quarters are anatomically and physiologically distinct from each other (Nickerson and Akers, 2011), so subclinical mastitis does not usually occur simultaneously in the 4 udder quarters (Barkema et al., 1997). When composite milk 
samples from individual cows are taken, the quarter with a high SCC and altered milk composition is often masked due to the milk from the healthy quarters of the same udder. This situation is particularly evident for moderate SCC alterations at the quarter level. It has been observed that in composite milk samples from cows with a low SCC $(<100,000$ cells/mL milk), more than $10 \%$ of the samples were hiding individual udder quarters with high levels of SCC and at least half were infected with pathogens (Berglund et al., 2002; Zecconi et al., 2019).

Some data are available on the effects of the SCC level on the milk composition of single quarters (Forsbäck et al., 2009; Malek dos Reis et al., 2013). However, to the best of our knowledge, there is a lack of studies on the relationship between the SCC and milk fatty acid (FA) profile of individual udder quarters, in relation to the different SCC levels. However, the FA detected in milk have different metabolic origins, hence it is not easy to find a clear pattern in the correlation between the milk FA using only univariate analysis (Mele et al., 2016). On the other hand, statistical approaches based on data reduction methods, such as principal component analysis and multivariate factor analysis (MFA), may be useful to highlight the detailed structure of the pattern of correlations among measured traits and to extract fewer latent phenotypically independent variables, which could better explain a specific metabolic pathway (Macciotta et al., 2004).

In dairy cattle, principal component analysis and MFA have been used to investigate the milk FA profile (Fievez et al., 2003; Conte et al., 2016; Mele et al., 2016; Cecchinato et al., 2019), milk composition, milk protein profile, and cheese-making properties (Macciotta et al., 2012; Dadousis et al., 2017). We hypothesized that by reducing the complex milk FA pattern to a few synthetic variables, the pattern of the mutual relationship among milk FA might be more informative than univariate analysis regarding the role of different SCC levels of individual udder quarters on the mammary lipid metabolism.

\section{MATERIALS AND METHODS}

\section{Animals}

A total of 49 Italian Holstein cows were selected from the dairy farm of the University of Pisa (Centro di Ricerche Agro-ambientali "E. Avanzi," Pisa, Italy). All animals were raised in the same environment and under the same feeding regimen. The average parity and lactation weeks were $2.1 \pm 1.1$ and $24.6 \pm 16.9$, respectively, and the average milk production was $23 \pm$
$5.8 \mathrm{~kg} / \mathrm{d}$. Individual milk samples separated by quarter were collected at the evening milking on 2 different days. All cows were sampled at the same time per each sampling day. None of the cows showed clear clinical mastitis symptoms.

Before milking, teat ends were scrubbed with $70 \%$ ethanol, and the first 2 squirts of milk were discarded. Milk sampling tubes, containing approximately 50 $\mathrm{mL}$ of milk, were prepared with $1 \mathrm{~mL}$ (20\% wt/vol) of 2-bromo-2-nitropro-pane-1,3-diol (bronopol; VWR International AB, Stockholm, Sweden). A total of 392 milk samples were obtained by complete milking of individual quarters. From the total milk collected for each quarter, 2 aliquots of milk were taken: one was stored at $4^{\circ} \mathrm{C}$ and used for SCC level determination, whereas the other was stored at $-20^{\circ} \mathrm{C}$ for $\mathrm{FA}$ profile analysis.

\section{Milk SCC and Fatty Acid Profile}

The milk samples were analyzed for SCC by electronic fluorescence-based cell counting (Fossomatic 5000, A/S N. Foss, Hillerød, Denmark). Quarters were classified on the basis of the SCC level as follows: very healthy group $(<10,000$ cells $/ \mathrm{mL})$, healthy group $(10,000-$ 100,000 cells $/ \mathrm{mL}$ ), moderate subclinical mastitis group $(100,000-400,000$ cells $/ \mathrm{mL})$, and severe subclinical mastitis group ( $>400,000$ cells $/ \mathrm{mL})$. This classification is based on the one proposed by Merle et al. (2007), but splitting the group of healthy quarters $(<100,000$ cells/ $\mathrm{mL}$ ) into very healthy and healthy. This was because significant differences were observed in the pathogen contamination between quarters with a lower or higher SCC level than 10,000 cells/mL (Schwarz et al., 2010).

Fatty acid methyl esters of milk were prepared by the direct extraction and alkali catalyzed trans-methylation procedure, and the profile was determined by GC, as described by Conte et al. (2016). Briefly, a GC2010 Shimadzu gas chromatograph (Shimadzu, Columbia, MD) equipped with a flame ionization detector and a high polar fused-silica capillary column (Chrompack CP-Sil88, Varian, Middelburg, the Netherlands; 100 m, $0.25 \mathrm{~mm}$ i.d.; film thickness $0.20 \mathrm{~mm}$ ) was used for the analysis. Hydrogen was used as the carrier gas at a flow of $1 \mathrm{~mL} / \mathrm{min}$, whereas the split/splitless injector ratio was 1:80. An aliquot of the sample was injected under the following $\mathrm{GC}$ conditions: the oven temperature was heated to $60^{\circ} \mathrm{C}$ and maintained at that level for $1 \mathrm{~min}$; the temperature was then increased to $173^{\circ} \mathrm{C}$ at a rate of $2^{\circ} \mathrm{C} / \mathrm{min}$, and maintained at that level for $30 \mathrm{~min}$ before being once again increased to $185^{\circ} \mathrm{C}$ at $1^{\circ} \mathrm{C} / \mathrm{min}$ and held for $5 \mathrm{~min}$, and then to $220^{\circ} \mathrm{C}$ at a rate of $3^{\circ} \mathrm{C} / \mathrm{min}$, and maintained for $19 \mathrm{~min}$. The injector and 
detector temperatures were set at $270^{\circ} \mathrm{C}$ and $300^{\circ} \mathrm{C}$, respectively.

Individual FAME were identified by comparison with a standard mixture of 52 Component FAME Mix (Nu-Chek Prep Inc., Elysian, MN). The identification of C18:1 isomers was based on commercial standard mixtures (Supelco, Bellefonte, PA) and published isomeric profiles (Kramer et al., 2008). A reference standard butter (BCR 164; Commission of the European Communities, Community Bureau of Reference, Brussels, Belgium) was used to estimate correction factors for short-chain fatty acids (SCFA), according to the protocol described by Mele et al. (2009). Inter- and intraassay coefficients of variation were also calculated using the same reference standard butter; the detection limit of the analysis was $0.001 \%$ above the total FA amount. Milk FA composition was expressed as grams per $100 \mathrm{~g}$ of total FA.

\section{Statistical Analysis}

Multivariate Analysis. The milk FA profile was analyzed by a multivariate approach, using the MFA. The main aim of MFA is to explain the (co)variance of a system described by $n$ measured traits $(\mathrm{y} 1, \ldots, \mathrm{yn})$ by deriving a smaller number $\mathrm{p}(\mathrm{p}<\mathrm{n})$ of latent unobservable variables $(\mathrm{X} 1, \ldots, \mathrm{Xp})$, named the common latent factors.

Factor analysis considers the variance of each original variable as a combination of common and unique components, named communality and uniqueness, respectively (Morrison, 1976; McDonald, 1985), using the following factor model:

$$
\mathrm{S}=\mathbf{B B}^{\prime}+\Psi
$$

where $\mathbf{S}$ is the covariance matrix of the measured traits, and $\mathbf{B B}^{\prime}$ and $\boldsymbol{\Psi}$ are the communality and the uniqueness (co)variance matrices, respectively (Morrison, 1976).

The MFA was performed using the principal factor method and the VARIMAX orthogonal rotation technique. The MFA starts with a linear modeling of observed variables in terms of a limited set of latent variables (Macciotta et al., 2012):

$$
\begin{aligned}
& y_{1}=b_{11} X_{1}+\ldots \ldots+b_{1 p} X_{p}+e_{1}, \\
& y_{n}=b_{n 1} X_{1}+\ldots \ldots+b_{n p} X_{p}+e_{n},
\end{aligned}
$$

where $X_{j}$ is the $j$ th common factor, $b_{i j}$ are factor coefficients (or loadings; i.e., correlations between the $j$ th common factor), and $e_{i}$ is the $i$ th residual specific variable. Loadings are the elements of the $\mathbf{B}$ matrix of the theoretical factor variance model.

The MFA extracts different sets of common latent factors via the rotation technique (McDonald, 1985). Such flexibility simplifies the factor structure and facilitates their interpretation in terms of the relationships with the original variables (McDonald, 1985).

The suitability of the data set for factor analysis was evaluated by a comparison between phenotypic Pearson and partial correlation values. Partial correlations measure the relationships between each pair of variables, considering all possible effects of the other variables (Macciotta et al., 2004). The difference between Pearson and partial correlations is evaluated by the Kaiser measure of sampling adequacy (MSA), which quantifies the difference between the off-diagonal elements of the matrix of the original variables and the anti-image correlation matrix $\mathbf{Q}=\mathbf{P S}^{-1} \mathbf{P}$, where $\mathbf{S}=$ matrix of the original variables, and $\mathbf{P}=\left[\operatorname{diag}\left(\mathbf{S}^{-1}\right)\right]^{-1}$ (Cerny and Kaiser, 1977).

Factor analysis was carried out on the correlation matrix that was made up of 61 single FA (C4:0, C6:0, $\mathrm{C} 8: 0, \mathrm{C} 10: 0$ iso, C10:0, C10:1 cis-9, C11:0, C12:0 iso, $\mathrm{C} 12: 0$ anteiso, C12:0, C13:0 iso, C12:1 cis-11, C13:0, C14:0 iso, C14:0 anteiso, C14:0, C14:1 cis-9, C15:0 iso, $\mathrm{C} 15: 0$ anteiso, C15:0, C16:0 iso, C16:0, C16:1 trans-6/7, C16:1 trans-9, C17:0 iso, C16:1 cis-7, C16:1 cis-9, C17:0 anteiso, C17:0, C18:0, C18:1 trans-4, C18:1 trans-6-8, $\mathrm{C} 18: 1$ trans-9, C18:1 trans-10, C18:1 trans $-11, \mathrm{C} 18: 1$ trans-12, C18:1 cis-9, C18:1 trans-15, C18:1 cis-11, C18:1 cis-12, C18:1 cis-13, C18:1 trans-16, C18:2 trans9,trans-12, C18:2n-6, C20:0, C18:3n-6, C20:1 cis-8, C18:3n-3, C18:2 cis-9,trans-11, C21:0, C20:2n-6, C18:3 cis-9,trans-11,cis-15, C22:0, C20:3n-6, C20:3n-3, C20: 4n-6, C23:0, C20:5n-3, C24:0, C22:4n-6, and C22:5n-3) measured in the 392 udder quarters.

We chose the number of latent variables according to their eigenvalue $(>1)$, the amount of variance explained by the extracted factors, and their readability in terms of biological significance and relationships with the original variables (Morrison, 1976). In accordance with Macciotta et al. (2015), a variable was considered to be associated with a specific factor if the absolute value of its loading was $\geq 0.60$.

Factor scores were calculated for each cow according to the following formula:

$$
\mathbf{x}^{\prime}=\mathbf{y}^{\prime} \times\left(\mathbf{B B}^{\prime}+\mathbf{\Psi}\right)^{-1} \times \mathbf{B},
$$

where $\mathbf{x}^{\prime}$ is the row vector of factor scores, $\mathbf{y}^{\prime}$ is the row vector of standardized [(value - mean)/standard 
Table 1. Somatic cell count of 392 single quarters of Italian Holstein-Friesian cows: descriptive statistics

\begin{tabular}{|c|c|c|c|c|}
\hline & Very healthy & Healthy & Moderate subclinical mastitis & Severe subclinical mastitis \\
\hline Number of quarters & 91 & 197 & 68 & 36 \\
\hline Mean & 6,619 & 28,318 & 173,227 & $2,886,500$ \\
\hline Median & 7,000 & 21,000 & 160,000 & $1,474,000$ \\
\hline Maximum & 10,000 & 98,000 & 384,000 & $6,629,000$ \\
\hline SD & 2,961 & 20,118 & 68,760 & $4,163,134$ \\
\hline $\mathrm{CV} \%$ & 44.73 & 71.04 & 39.69 & 69.33 \\
\hline Kurtosis & -1.06 & 2.69 & 2.15 & 16.29 \\
\hline
\end{tabular}

deviation] traits. Standardized, rather than raw values, were used because analyzed traits had different units of measurement and scale.

Mixed Model Analysis. To evaluate the relationship between common factors and SCC level, individual factor scores were analyzed with the following mixed linear model:

$$
\begin{gathered}
y_{i j q z w}=\mu+\mathrm{SCC}_{i}+\mathrm{DIM}_{j}+\operatorname{parity}_{q}+D_{z} \\
+\operatorname{cow}_{w}+\varepsilon_{i j q z w},
\end{gathered}
$$

where $y_{i j g z w}=$ individual scores of factors; $\mathrm{SCC}_{i}=$ fixed effect of the $i$ th SCC level $(<10,000,10,000$ to 100,000 , 100,000-400,000, >400,000 cells $/ \mathrm{mL}) ; \mathrm{DIM}_{j}=$ fixed effect of the $j$ th class of days in milking $(<100,100-200$, $>200$ ); $\operatorname{parity}_{q}=$ fixed effect of the $q$ th parity (first, second, $\geq$ third); $D_{z}=$ fixed effect of the $z$ th day of sampling (first, second); $\operatorname{cow}_{w}=$ random effect of the wth (49 levels); and $\varepsilon_{i j g z w}=$ random residual. The effects were declared significant at $P<0.05$. Multiple comparisons among means were performed by Tukey's test, with significance considered at $P<0.05$.

The linear and quadratic relationship between the scores of factors 1 and 4 and SCC values expressed as linear score (LS) were also tested. Linear score was calculated using the following formula (Allore et al., 1998):

$$
\mathrm{LS}=\frac{\ln \left(\frac{\mathrm{n}}{12,500}\right)}{\ln (2)},
$$

where $\ln =$ natural logarithm (base e), and $\mathrm{n}=$ number of somatic cells per milliliter.

Values correspond to the least squares means $( \pm \mathrm{SE})$ of intercepts and linear or quadratic (or both) regression coefficients.

\section{RESULTS AND DISCUSSION}

\section{SCC and Milk Fatty Acid Composition of Single Udder Quarters}

The SCC ranged from 1,000 cells/mL up to $6,629,000$ cells $/ \mathrm{mL}$ in milk from individual udder quarters (Table 1). A high variability in the cell count within each udder was observed. However, the statistical analysis showed no correlations between SCC and udder half (front or back) or udder quarter position (data not shown).

All quarters were considered healthy if their SCC level was lower than 100,000 cells $/ \mathrm{mL}$. The percentage of cows with all healthy quarters was lower than $40 \%$ (30\% and 39\% in the first and second sampling, respectively). Approximately $30 \%$ of cows only had one quarter affected (28\% and $31 \%$ in the first and second sampling, respectively), whereas, on average, nearly $36 \%$ of cows had 2 or 3 quarters affected ( $42 \%$ and $30 \%$ in the first and second samplings, respectively).

Considering the quarters of both samplings, 91 quarters were identified with $<10,000$ cells $/ \mathrm{mL}, 197$ quarters with SCC between 10,000 and 100,000 cells/mL, 68 quarters with SCC between 100,000 and 400,000 cells/mL, and 36 quarters with SCC >400,000 cells/ $\mathrm{mL}$ (Table 1). The quarters were evenly distributed between the various stages of lactation and parity.

Descriptive statistics of the milk FA composition are reported in Table 2. Saturated fatty acid was the most abundant class (accounting for almost $65.5 \%$ ), followed by MUFA and PUFA accounting for $30 \%$ and $4 \%$, respectively. Medium-chain FA (MCFA) accounted for more than $50 \%$, followed by long-chain FA and SCFA. In agreement with Gaspardo et al. (2010) and Conte et al. (2016), C16:0, the sum of C18:1 isomers, C18:0, and C14:0 were the most abundant FA in cow milk. The coefficient of variation was higher for MUFA, followed by PUFA and SFA, with SFA accounting for $8 \%$, in agreement with previous data reported for Holstein- 
Table 2. Mean, SD, CV, minimum (Min), and maximum (Max) values for fatty acids of 392 single quarters from 49 Italian Holstein-Friesian cows

\begin{tabular}{|c|c|c|c|c|c|c|}
\hline Item & Mean & $\mathrm{SD}$ & $\mathrm{CV} \%$ & Min & $\operatorname{Max}$ & Kurtosis \\
\hline \multicolumn{7}{|l|}{ SFA } \\
\hline $\mathrm{C} 4: 0$ & 2.23 & 0.34 & 15.24 & 0.37 & 4.63 & 8.83 \\
\hline C6:0 & 1.40 & 0.27 & 19.28 & 0.26 & 2.44 & 1.73 \\
\hline C8:0 & 0.82 & 0.19 & 23.17 & 0.00 & 0.26 & 1.24 \\
\hline C10:0 iso & 0.03 & 0.01 & 33.33 & 0.00 & 0.26 & 1.37 \\
\hline C10:0 & 1.94 & 0.51 & 26.28 & 0.50 & 2.95 & 0.80 \\
\hline C11:0 & 0.02 & 0.01 & 50.00 & 0.00 & 0.07 & 1.16 \\
\hline $\mathrm{C} 12: 0$ iso & 0.02 & 0.01 & 50.00 & 0.00 & 0.23 & 2.49 \\
\hline $\mathrm{C} 12: 0$ anteiso & 0.02 & 0.01 & 50.00 & 0.00 & 0.25 & 2.06 \\
\hline $\mathrm{C} 12: 0$ & 2.20 & 0.60 & 27.27 & 0.56 & 3.59 & 0.68 \\
\hline C13:0 iso & 0.03 & 0.01 & 33.33 & 0.00 & 0.17 & 3.03 \\
\hline C13:0 & 0.07 & 0.02 & 28.57 & 0.00 & 0.12 & 0.11 \\
\hline $\mathrm{C} 14: 0$ iso & 0.13 & 0.05 & 38.46 & 0.04 & 0.29 & 1.50 \\
\hline $\mathrm{C} 14: 0$ anteiso & 0.02 & 0.01 & 50.00 & 0.00 & 0.24 & 2.23 \\
\hline C14:0 & 10.79 & 2.18 & 20.20 & 3.99 & 14.11 & 1.29 \\
\hline $\mathrm{C} 15: 0$ iso & 0.29 & 0.07 & 24.13 & 0.11 & 0.53 & 0.95 \\
\hline C15:0 anteiso & 0.66 & 0.15 & 22.72 & 0.26 & 1.08 & 0.71 \\
\hline C15:0 & 1.19 & 0.21 & 17.64 & 0.58 & 1.72 & 0.98 \\
\hline C16:0 iso & 0.28 & 0.07 & 25.00 & 0.13 & 0.57 & 2.23 \\
\hline C16:0 & 30.87 & 3.88 & 12.56 & 22.49 & 42.00 & -0.33 \\
\hline $\mathrm{C} 17: 0$ iso & 0.42 & 0.06 & 14.28 & 0.26 & 0.88 & 8.93 \\
\hline C17:0 anteiso & 0.63 & 0.08 & 12.70 & 0.45 & 1.12 & 3.50 \\
\hline $\mathrm{C} 17: 0$ & 0.72 & 0.16 & 22.22 & 0.51 & 1.42 & 4.58 \\
\hline C18:0 iso & 0.05 & 0.03 & 60.00 & 0.01 & 0.17 & 3.20 \\
\hline C18:0 & 10.24 & 1.91 & 18.65 & 6.33 & 16.45 & 0.17 \\
\hline $\mathrm{C} 20: 0$ & 0.19 & 0.04 & 21.05 & 0.07 & 0.48 & 12.59 \\
\hline C21:0 & 0.06 & 0.02 & 33.33 & 0.01 & 0.13 & 2.27 \\
\hline $\mathrm{C} 22: 0$ & 0.07 & 0.02 & 28.57 & 0.01 & 0.22 & 4.18 \\
\hline $\mathrm{C} 23: 0$ & 0.05 & 0.02 & 40.00 & 0.01 & 0.20 & 8.97 \\
\hline $\mathrm{C} 24: 0$ & 0.05 & 0.02 & 40.00 & 0.01 & 0.21 & 9.96 \\
\hline \multicolumn{7}{|l|}{ MUFA } \\
\hline $\mathrm{C} 10: 1$ cis-9 & 0.18 & 0.06 & 33.33 & 0.01 & 0.32 & 0.39 \\
\hline C12:1 cis-11 & 0.05 & 0.02 & 40.00 & 0.00 & 0.14 & 0.74 \\
\hline C14:1 cis-9 & 0.94 & 0.29 & 30.85 & 0.30 & 1.62 & -0.36 \\
\hline $\mathrm{C} 16: 1$ trans $-6-7$ & 0.02 & 0.01 & 50.00 & 0.01 & 0.08 & 7.56 \\
\hline C16:1 trans-9 & 0.04 & 0.01 & 25.00 & 0.01 & 0.09 & 1.22 \\
\hline $\mathrm{C} 16: 1$ cis-7 & 0.19 & 0.04 & 21.05 & 0.12 & 0.43 & 10.50 \\
\hline C16:1 cis-9 & 1.46 & 0.29 & 19.86 & 0.70 & 2.39 & 0.17 \\
\hline $\mathrm{C} 17: 1$ cis-9 & 0.31 & 0.10 & 32.26 & 0.15 & 0.68 & 2.59 \\
\hline $\mathrm{C} 18: 1$ trans -4 & 0.02 & 0.01 & 50.00 & 0.00 & 0.13 & 3.59 \\
\hline C18:1 trans $-6-8$ & 0.29 & 0.05 & 17.24 & 0.17 & 0.47 & 0.02 \\
\hline C18:1 trans-9 & 0.21 & 0.04 & 19.05 & 0.11 & 0.37 & 0.72 \\
\hline C18:1 trans -10 & 0.33 & 0.10 & 30.30 & 0.14 & 0.81 & 3.40 \\
\hline C18:1 trans- 11 & 1.14 & 0.27 & 23.68 & 0.58 & 2.15 & 1.66 \\
\hline C18:1 trans- 12 & 0.43 & 0.11 & 25.58 & 0.11 & 0.77 & -0.08 \\
\hline C18:1 cis-9 & 23.12 & 4.67 & 20.20 & 15.40 & 37.48 & 1.51 \\
\hline C18:1 trans -15 & 0.32 & 0.10 & 31.25 & 0.11 & 0.60 & -0.46 \\
\hline $\mathrm{C} 18: 1$ cis-11 & 0.51 & 0.21 & 41.18 & 0.19 & 1.92 & 6.61 \\
\hline $\mathrm{C} 18: 1$ cis-12 & 0.33 & 0.10 & 30.30 & 0.14 & 0.76 & 0.95 \\
\hline C18:1 cis-13 & 0.05 & 0.04 & 80.00 & 0.01 & 0.26 & 6.51 \\
\hline $\mathrm{C} 18: 1$ trans -16 & 0.33 & 0.08 & 24.24 & 0.04 & 0.51 & 1.05 \\
\hline C20:1 cis-8 & 0.14 & 0.05 & 35.71 & 0.02 & 0.70 & 4.61 \\
\hline \multicolumn{7}{|l|}{ PUFA } \\
\hline C18:2 trans -9, trans- 12 & 0.23 & 0.10 & 43.48 & 0.04 & 0.80 & 1.24 \\
\hline C18:2 trans-11,cis-15 & 0.15 & 0.05 & 33.33 & 0.02 & 0.37 & 3.13 \\
\hline $\mathrm{C} 18: 2 \mathrm{n}-6$ & 1.87 & 0.36 & 19.25 & 1.07 & 2.96 & -0.15 \\
\hline C18:3n-6 & 0.02 & 0.02 & 50.00 & 0.00 & 0.26 & 15.53 \\
\hline $\mathrm{C} 18: 3 \mathrm{n}-3$ & 0.70 & 0.13 & 18.57 & 0.41 & 1.17 & 0.12 \\
\hline C18:2 cis- 9, trans -11 & 0.54 & 0.12 & 22.22 & 0.24 & 1.14 & 2.49 \\
\hline $\mathrm{C} 20: 2 \mathrm{n}-6$ & 0.04 & 0.01 & 25.00 & 0.00 & 0.09 & 0.16 \\
\hline C18:3 cis-9,trans-11,cis-15 & 0.03 & 0.01 & 33.33 & 0.00 & 0.08 & 0.74 \\
\hline $\mathrm{C} 20: 3 n-6$ & 0.09 & 0.03 & 33.33 & 0.01 & 0.23 & 7.52 \\
\hline $\mathrm{C} 20: 3 \mathrm{n}-3$ & 0.02 & 0.02 & 50.00 & 0.01 & 0.28 & 6.89 \\
\hline C20:4n-6 & 0.16 & 0.05 & 31.25 & 0.06 & 0.56 & 12.94 \\
\hline C20:5n-3 & 0.05 & 0.02 & 40.00 & 0.01 & 0.10 & 0.96 \\
\hline
\end{tabular}


Table 2 (Continued). Mean, SD, CV, minimum (Min), and maximum (Max) values for fatty acids of 392 single quarters from 49 Italian Holstein-Friesian cows

\begin{tabular}{lrrrrrr}
\hline Item & Mean & SD & CV\% & Min & Max & Kurtosis \\
\hline C22:4n-6 & 0.03 & 0.03 & 33.33 & 0.00 & 0.38 & 6.94 \\
C22:5n-3 & 0.17 & 0.16 & 94.12 & 0.03 & 2.87 & 8.75 \\
Class of fatty acids $^{1}$ & & & & & & \\
SFA & 65.50 & 5.21 & 7.95 & 48.59 & 78.39 & 0.85 \\
MUFA & 30.40 & 4.93 & 16.22 & 21.75 & 45.91 & 1.10 \\
PUFA & 4.12 & 0.56 & 13.59 & 2.76 & 7.46 & 3.23 \\
SCFA & 6.62 & 1.13 & 17.07 & 1.79 & 10.97 & 1.89 \\
MCFA & 51.36 & 5.92 & 11.53 & 36.63 & 64.63 & 0.06 \\
LCFA & 42.06 & 6.71 & 15.95 & 28.40 & 60.37 & 0.26 \\
VLCFA & 1.13 & 0.27 & 23.89 & 0.60 & 4.08 & 3.80 \\
BCFA & 2.59 & 0.36 & 13.90 & 1.75 & 3.86 & 1.23 \\
OCFA & 4.42 & 0.48 & 10.86 & 3.35 & 6.27 & 1.56 \\
\hline
\end{tabular}

${ }^{1} \mathrm{SCFA}=$ short-chain fatty acids (acyl chain less than 11 carbon atoms); MCFA = medium-chain fatty acids (acyl chain more than 10 carbon atoms and less than 17 carbon atoms); LCFA = long-chain fatty acids (acyl chain more than 16 carbon atoms); VLCFA = very long chain fatty acids; BCFA = branched-chain fatty acids; OCFA $=$ odd-chain fatty acids.

Friesian (Stoop et al., 2008; Mele et al., 2009; Conte et al., 2016). We observed no effect of mammary quarter position on milk FA composition (data not showed), as revealed by Forsbäck et al. (2009) for fat and protein content.

\section{Milk Fatty Acid Composition: Multifactorial Analysis}

The MFA extracted 7 latent factors from the 64 variables measured, accounting for about $95 \%$ of the total variance (Table 3). Fatty acids with a loading score greater than 0.6 were considered as the most explained by a given factor. The factor pattern (derived from the correlations between each factor and the original variables) was reasonably easy to read. A relatively small number of variables showed correlations $\geq 0.60$ in each factor, whereas the rest had very low correlations (in many cases close to zero). The patterns across factors reveal each variable was highly correlated with only one factor. The suitability of the data set in terms of MFA was also further evaluated by calculating the Kaiser MSA, which measures the difference between Pearson and partial correlations. In our study, the Kaiser MSA value was 0.75 , close to the empirical threshold of 0.80 , which indicates the suitability of the individual variables used in the analysis (Macciotta et al., 2012). In fact, values of the partial correlations were markedly lower than the Pearson correlations, which suggests that the link between 2 variables is mediated by other variables in the data set, representing the best conditions for a MFA.

The partitioning of the variance between the factors is balanced, with an expected small predominance of factor 1 (eigenvalue $=14.41$ ), whereas the eigenvalues of the other 6 factors ranged between 1.38 and 9.37
(Table 3). This is a particular feature of the analysis of factors compared with the analysis of the main components, which is another multivariate technique that reduces the dimensionality size of the variables, where the variance of the first component is considerably greater than the subsequent ones (Jombart et al., 2009).

The first latent factor (factor 1) showed a positive correlation with all SCFA and MCFA except for C4:0, C16:0, and all branched- (BCFA) and odd- (OCFA) chain FA, and a negative correlation with C18:1 cis-9 (Table 3 ), in agreement with previous reports on dairy cattle, which determined a factor with a similar loading structure (Conte et al., 2016; Mele et al., 2016). For this reason, factor 1 was named de novo synthesis because it explained the common origin of SCFA and MCFA, which are synthesized in the mammary gland starting with acetate by the acetyl CoA carboxylase and fatty acid synthase enzymes (Chilliard et al., 2001). The first latent factor was therefore associated with the mammary gland activity and, in particular, with the regulation of milk fat fluidity. The esterification of de novo SCFA (from 4 to 10 carbons) and C18:1 cis-9 at positions n-3 of glycerol plays a crucial role in the regulation of milk fat fluidity (Chilliard et al., 2014; Toral et al., 2015).

The second latent factor (factor 2) correlated positively with C16:0, C16:1 cis-7, and C16:1 cis-9 and correlated negatively with $\mathrm{C} 18: 0$ (Table 3 ). These FA accumulate in milk from 2 different pathways. The C16:0, C16:1 cis-7, and C16:1 cis-9 are mainly the product of the synthesis of FA at the udder level. The C16:0, in fact, is the last step in the biosynthesis of FA, whereas C16:1 cis-9 derives from the desaturation of the previous one by stearoyl CoA desaturase (SCD; Mele et al., 2007). 


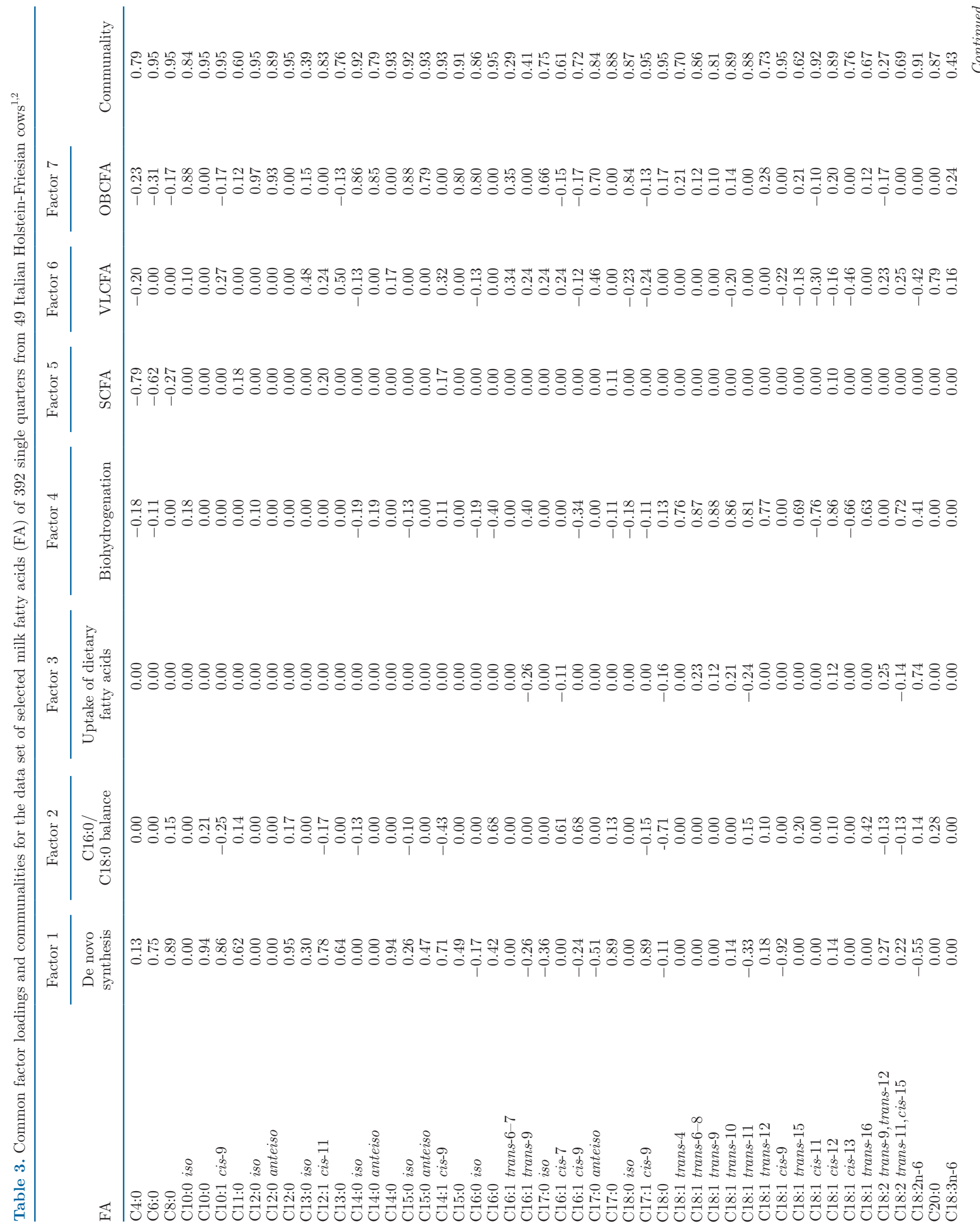




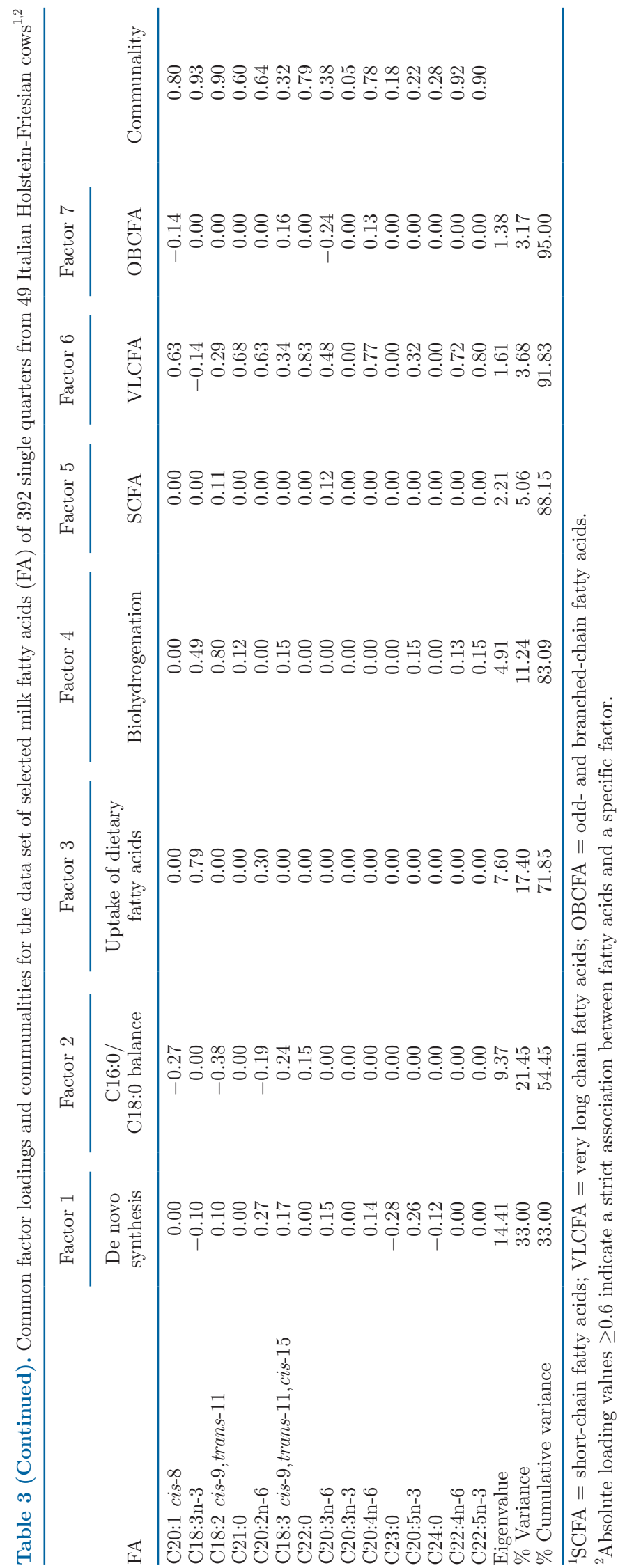

The C18:0 cannot be synthesized by the mammary gland and is derived from the bloodstream through different sources: (1) dietary FA as affected by ruminal biohydrogenation (Vlaeminck et al., 2006), and (2) mobilization of lipid deposits (Mele et al., 2007). This factor has been called C16:0/C18:0 balance to highlight the lipid source mainly used by the mammary gland for the synthesis of milk fat. As is known from the literature, C16:0 is representative of mammary FA biosynthesis, whereas $\mathrm{C} 18: 0$ and $\mathrm{C} 18: 1$ cis-9 are the most representative FA coming from outside of mammary gland (Loften et al., 2014; Conte et al., 2017). Douglas et al. (2007) found different concentrations of C16:0, C18:0, and C18:1 cis-9 among blood and body tissues that changed with the progression of lactation. However, C16:0 and C18:0 have been proposed to have a complementary role in lipid and energetic metabolism of the dairy cow (Loften et al., 2014). Several works have demonstrated that $\mathrm{C} 16: 0$ and $\mathrm{C} 18: 0$ had opposite trends in relationship to the energy balance (Dann et al., 2005; Kay et al., 2005; Stoop et al., 2009). Immediately after calving, when the cow is usually in a negative energy balance, the mammary de novo synthesis of FA is reduced, and milk FA are mainly derived from extramammary sources. In this case, the relative abundance of circulating C18:0 is higher, but C16:0 increases in milk fat more than C18:0 (Dann et al., 2005). According to the infusion study of Enjalbert et al. (1998), during the negative energy balance period, peripheral tissues prefer to incorporate $\mathrm{C} 18: 0$ as an energy source, whereas the mammary gland appears to prefer $\mathrm{C} 16: 0$ for incorporation into milk fat. Moreover, recent research suggested that $\mathrm{C} 16: 0$ and $\mathrm{C} 18: 0$ are important regulators of metabolism and gene transcription in ruminants (Bionaz et al., 2013). This may be an adaptive mechanism for ruminants to regulate metabolism in response to changes in availability of the more prevalent SFA. Finally, availabilities of C16:0 and C18:0 are considered signal changes in glucose metabolism (Bionaz et al., 2013).

The third latent factor (factor 3 ) correlated positively with the 2 main FA contained in the most common diets: linoleic acid (C18:2n-6) and $\alpha$-linolenic acid (C18: 3n-3; Table 3). This factor was therefore named uptake of dietary fatty acids because is positively related to the amount of the 2 FA escaping rumen biohydrogenation and available in the bloodstream for uptake from the mammary gland.

The fourth latent factor (factor 4) was associated with the FA derived from rumen biohydrogenation, and was therefore named biohydrogenation. This factor is positively associated with all C18:1 trans FA isomers, all $\mathrm{C} 18: 1$ cis isomers and C18:2 cis-9,trans-11 (the main conjugated isomer of linoleic acid; Table 3). All trans 
FA and $\mathrm{C} 18: 1$ cis isomers are intermediate products of rumen biohydrogenation and many of them can negatively affect the synthesis of FA of mammary origin (Conte et al., 2017). The positive association between the fourth latent factor and C18:2 cis-9,trans-11 was due to the origin of this FA, mainly due to the mammary desaturation of C18:1 trans-11 via the SCD enzyme (Mele et al., 2007).

The fifth factor (factor 5), named SCFA, correlated positively with C4:0 and C6:0 (Table 3). Thus, as previously reported by Mele et al. (2016), de novo FA were associated with 2 latent factors: one (factor 5) for C4:0 and C6:0 and one (factor 1) for longer FA up to C14:0. In fact, unlike medium-chain FA (from C10:0 to C14:0), C4:0 and C6:0 are partly synthesized by a metabolic pathway that is not dependent on acetyl CoA carboxylase (Chilliard et al., 2007). Thus, the pattern of FA association obtained in the present work confirmed findings previously reported after analyzing different and independent data sets.

Very long chain FA ( $\mathrm{C} \geq 20$, VLCFA) correlated positively with factor 6 , was named VLCFA (Table $3)$. In milk fat, VLCFA are mainly contained in the phospholipid fraction, which represents less than $2 \%$ of total lipids (Jensen, 2002). They are also produced in the mammary gland by the elongation of linoleic and $\alpha$-linolenic acids of dietary origin (Bionaz and Loor, 2008). High scores in this factor may indicate a cow that is more efficient in promoting the elongation of linoleic and $\alpha$-linolenic acid.

The seventh latent factor (factor 7) was named OBCFA and correlated positively with odd- and branchedchain FA (Table 3). These FA are mainly produced in the rumen: branched FA are synthesized by cellulolytic bacteria; thus, their content in milk is positively related to the amount of forage in the diet (Vlaeminck et al., 2006). On the other hand, odd-chain FA derive mainly from rumen microbes due to the repeated condensation of malonyl-CoA using propionate as a primer (Vlaeminck et al., 2006), which is abundant in rumen when diets are rich in nonstructural carbohydrates. Interestingly, C17:0 was associated with factor 1 together with its desaturation product (C17:1 cis-9; Fievez et al., 2003). This suggests that the metabolic role of C17:0 in milk fat secretion differs from the other odd-chain FA, probably due to its affinity with the SCD enzyme (Palmquist et al., 1993; Vlaeminck et al., 2006).

Among the FA included in the factor analysis, 11 FA were not associated with any of the 7 extracted factors. These acids were C13:0 iso, C16:1 trans-6-7, C16:1 trans- 9 , C18:2 trans-9,trans-12, C18:3n-6, C18:3 cis-9,trans-11,cis-15, C20:3n-6, C20:3n-3, C23:0, C20: 5n-3, and C24:0, which showed a communality value lower than 0.5. According to the theory of factor analysis, when a variable has a communality value of less than 0.5 , the explanatory force of the variable can be represented at an individual level and therefore is not associated with other variables. Thus, based on the factor analysis patterns, C16:1 trans-6-7 and C16:1 trans-9 were excluded from the 7 extracted factors.

\section{Effect of SCC on Common Latent Factor}

An increase in milk SCC has been associated with changes in milk composition (Linzell and Peaker, 1972; Hamann, 2003; Berglund et al., 2004); however, to the best of our knowledge, no previous works have analyzed the milk FA profile of the individual quarters as affected by the level of SCC.

The level of somatic cells in milk significantly affected the de novo synthesis and biohydrogenation factors (Table 4). Moving from the status of very healthy udders $(<10,000$ somatic cells) to healthy $(10,000$ to 100,000 somatic cells) and from healthy to moderate mastitis, values of the de novo synthesis factor decreased significantly. No differences were observed between the status of moderate subclinical mastitis and severe subclinical mastitis (Table 4). This suggests that very low levels of somatic cells in milk (less than 10,000) were associated with optimal synthesis of FA in the mammary gland. Interestingly, although an SCC between 10,000 and 100,000 is considered as healthy in relation to the mammary quarter, the capacity to synthesize de novo FA seemed to be partially reduced. Conversely, increasing levels of somatic cells are positively associated with C18:1 cis-9, suggesting that mammary gland quarters counter-balance the decreasing capacity to synthesize de novo FA with the increasing desaturation of C18:0 to C18:1 cis-9. The conversion of C18:0 (melting point: $69^{\circ} \mathrm{C}$ ) to $\mathrm{C} 18: 1$ cis-9 (melting point: $14^{\circ} \mathrm{C}$ ) through the action of $\Delta 9$-desaturase, decreases the fat melting point in milk with high level of SCC, with a consequent increase of milk fat fluidity (Toral et al., 2015). The necessity to maintain a constant milk fat melting point may induce a higher requirement for de novo FA, to facilitate the translocation and export of triacylglycerols from the mammary secretory cell (Toral et al., 2015). If such requirements cannot be met, the consequence is a decrease in triacylglycerol synthesis to accommodate changes in preformed FA supply to ensure efficient ejection of fat from the mammary gland (Toral et al., 2015). The association pattern of factor 1 may contribute to explain the reduction of milk fat in quarters with high SCC levels, observed by Forsbäck et al. (2009), as a reduction of de novo FA synthesis. This result demonstrates the ability of MFA to provide 
Table 4. Least squares means of latent factors for different SCC levels (cells $/ \mathrm{mL}$ )

\begin{tabular}{|c|c|c|c|c|c|c|}
\hline & $\begin{array}{c}\text { Very } \\
\text { healthy }\end{array}$ & Healthy & $\begin{array}{c}\text { Moderate } \\
\text { mastitis }\end{array}$ & $\begin{array}{l}\text { Severe } \\
\text { mastitis }\end{array}$ & & \\
\hline Factor $^{1}$ & $<10,000$ & $10,000-100,000$ & $100,000-400,000$ & $>400,000$ & SEM & $P$-value \\
\hline C16:0/C18:0 balance & 0.08 & -0.02 & 0.01 & -0.07 & 0.15 & NS \\
\hline Dietary fatty acids & 0.19 & -0.14 & -0.19 & 0.13 & 0.02 & NS \\
\hline Biohydrogenation & $-0.09^{\mathrm{b}}$ & $-0.08^{\mathrm{b}}$ & $0.11^{\mathrm{b}}$ & $0.37^{\mathrm{a}}$ & 0.14 & $*$ \\
\hline OBCFA & 0.01 & 0.00 & -0.10 & -0.05 & 0.15 & NS \\
\hline
\end{tabular}

${ }^{\mathrm{a}, \mathrm{b}} \mathrm{P} \leq 0.05 ;{ }^{\mathrm{A}-\mathrm{C}} \mathrm{P} \leq 0.01$.

${ }^{1} \mathrm{SCFA}=$ short-chain fatty acids; VLCFA $=$ very long chain fatty acids; OBCFA $=$ odd- and branched-chain fatty acids.

$* P<0.05 ; * * * P<0.001$.

different information, thanks to its ability to represent and describe specific metabolic pathways by extracting a few different factors.

When quarters were in the severe subclinical mastitis status (somatic cells $>400,000$ ), the reduced capacity to synthesize de novo FA was probably also counterbalanced by an increasing uptake of circulating FA, as suggested by the significant positive association between the biohydrogenation factor and milk SCC values (Table 4).

The higher level of biohydrogenation products in the quarter with SCC >400,000, as explained by factor 4, probably showed a negative effect in the mammary fat

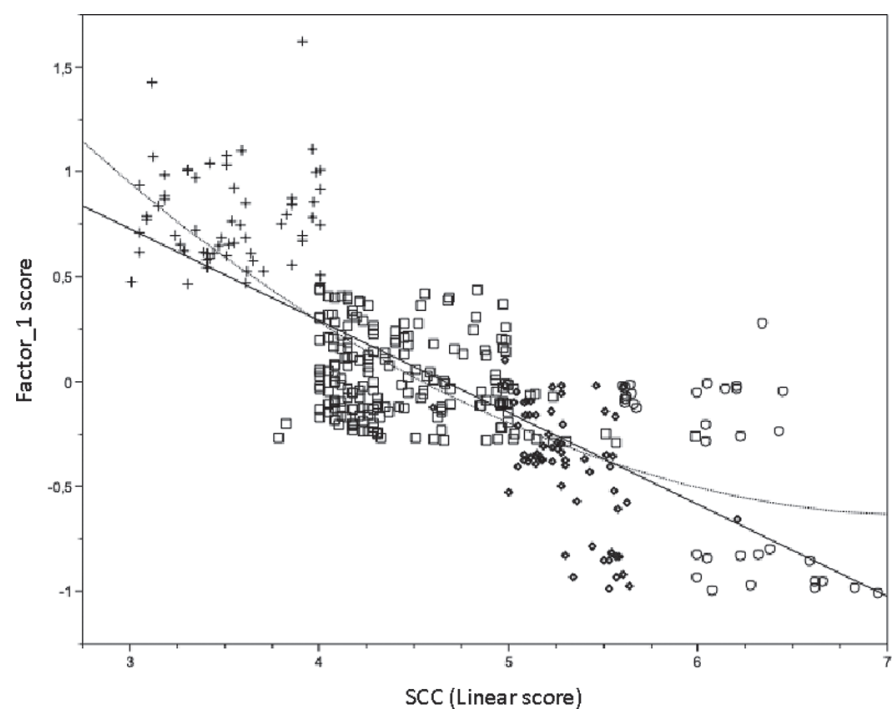

Figure 1. Relationship between SCC values (expressed as linear score) and scores of factor 1 . Continuous line $=$ linear effect $(y=$ $\left.-0.44 \mathrm{x}+2.04 ; \mathrm{R}^{2}=0.59 ; P<0.001\right) ;$ dashed line $=$ quadratic effect $\left(\mathrm{y}=0.09 \mathrm{x}^{2}-0.46 \mathrm{x}+2.11 ; \mathrm{R}^{2}=0.61 ; P<0.001\right) ;(+)$ quarters with SCC $<10,000$ cells $/ \mathrm{mL} ;(\square)$ quarters with $10,000<\mathrm{SCC} \leq 100,000$ cells $/ \mathrm{mL} ;(\diamond)$ quarters with $100,000<\mathrm{SCC}<400,000$ cells $/ \mathrm{mL} ;(\bigcirc)$ quarters with $\mathrm{SCC}>400,000$ cells $/ \mathrm{mL}$. synthesis. In a previous work, Cecchinato et al. (2019) demonstrated a negative genetic correlation between de novo FA and biohydrogenation factors. Specific biohydrogenation products have been observed to be effective in the inhibition of milk fat synthesis (Bauman and Griinari, 2001). It has been reported that C18:1 trans-10 strongly reduces the expression of FA synthase, SCD, and sterol regulatory element binding transcription factor 1 in bovine mammary epithelial cells, providing support for its potential anti-lipogenic properties (Kadegowda et al., 2009).

Figures 1 and 2 showed both linear and quadratic relationship by plotting linear score of SCC against the scores of factors 1 and 4 (the 2 factors showing a significant effect on the SCC classes in the ANOVA). In both cases, values of linear score related to the moderate mastitis class (SCC level 100,000-400,000 cells/ $\mathrm{mL}$ ) were clearly separated by the severe mastitis group (SCC level >400,000 cells $/ \mathrm{mL}$ ). According to this pattern, SCC values $>100,000$ cells $/ \mathrm{mL}$ were associated with significant changes in mammary metabolism, confirming what has already been proposed in previous studies, which showed clinical cases in quarters with SCC levels between 100,000 and 200,000 cells/mL (Paape et al., 2002, 2003; Merle et al., 2007; Schwarz et al., 2010).

\section{Evaluation of SCC Effect on Quarters of the Same Udder}

To evaluate the ability of the de novo synthesis factor (factor 1) to differentiate between a single udder quarter with a different SCC count and the other quarters of the same udder, the de novo synthesis factor scores (8 scores for each cow: 1 score for each quarter per 2 sampling times) were plotted in pairs on a system of Cartesian axes with the scores of the second, third, fourth, and fifth factors, which described the principal 
mammary metabolism of FA. A score plot was obtained for each cow, and examples of individual score plots are reported in Figure 3.

Based on the value of the 8 scores of the de novo synthesis factor for each cow, 3 different patterns were obtained: pattern 1 ( 8 scores had positive values for the de novo synthesis factor and are plotted in the same area on the right-hand side of the $\mathrm{x}$-axis: 31 cows out of 49 showed this pattern; Figure 3a); pattern 2 [1 score had a positive value for the de novo synthesis factor (right-hand side of the $\mathrm{x}$-axis) and 7 scores had negative values and are plotted on the left-hand side of the x-axis: 11 cows out of 49 showed this pattern; Figure $3 \mathrm{~b}]$; pattern 3 [7 scores had positive values for the de novo synthesis factor (right side of the $\mathrm{x}$-axis) and 1 score had a negative value and is plotted on the lefthand side of the x-axis: 7 cows out of 49 showed this pattern; Figure 1c].

According to the SCC of the single quarters, pattern 1 represented the healthy mammary gland: all the quarters had an SCC of less than 10,000 and the de novo synthesis factor scores were all higher than zero. With regard to patterns 2 and 3, a single quarter was differentiated from the other 3 quarters according to a different level of SCC. In pattern 2, only 1 quarter out of the 4 had a positive score for factor 1, with an SCC value lower than 10,000 cells $/ \mathrm{mL}$ (Figure $3 \mathrm{~b}$ ). In pat- tern 3 , only 1 quarter out of 4 had a negative score for factor 1, with an SCC value higher than 100,000 cells/ $\mathrm{mL}$ (Figure 3c).

The different position of a single quarter in the graph is strictly linked to an SCC threshold, differentiating between very healthy quarters (positive value of factor 1 ), healthy quarters (score of factor 1 around zero), and potentially infected quarters (negative scores of factor 1).

Given these distribution patterns, the de novo synthesis of milk FA could thus be considered as an effective marker of udder health.

Several studies have demonstrated that changes in milk composition (fat, protein, lactose, minerals, and enzyme concentration modifications) caused by clinical mastitis or associated with high SCC values may be explained by mammary epithelial cell damage, which, in turn, is associated with a decrease in the synthesis of milk components. This is usually associated with an increase in vascular permeability and in the passage of immunoglobulins, serum protein, and minerals (sodium and chloride), and an increase in proteolytic activities (Cunha et al., 2008; Malek dos Reis et al., 2013). The relative day-to-day variation in SCC in healthy udders is $10 \%$ (Sjaunja 1986). This variation is likely not related to inflammation (Klastrup et al., 1987). Disturbances in the cows' routines and the unpredictability of

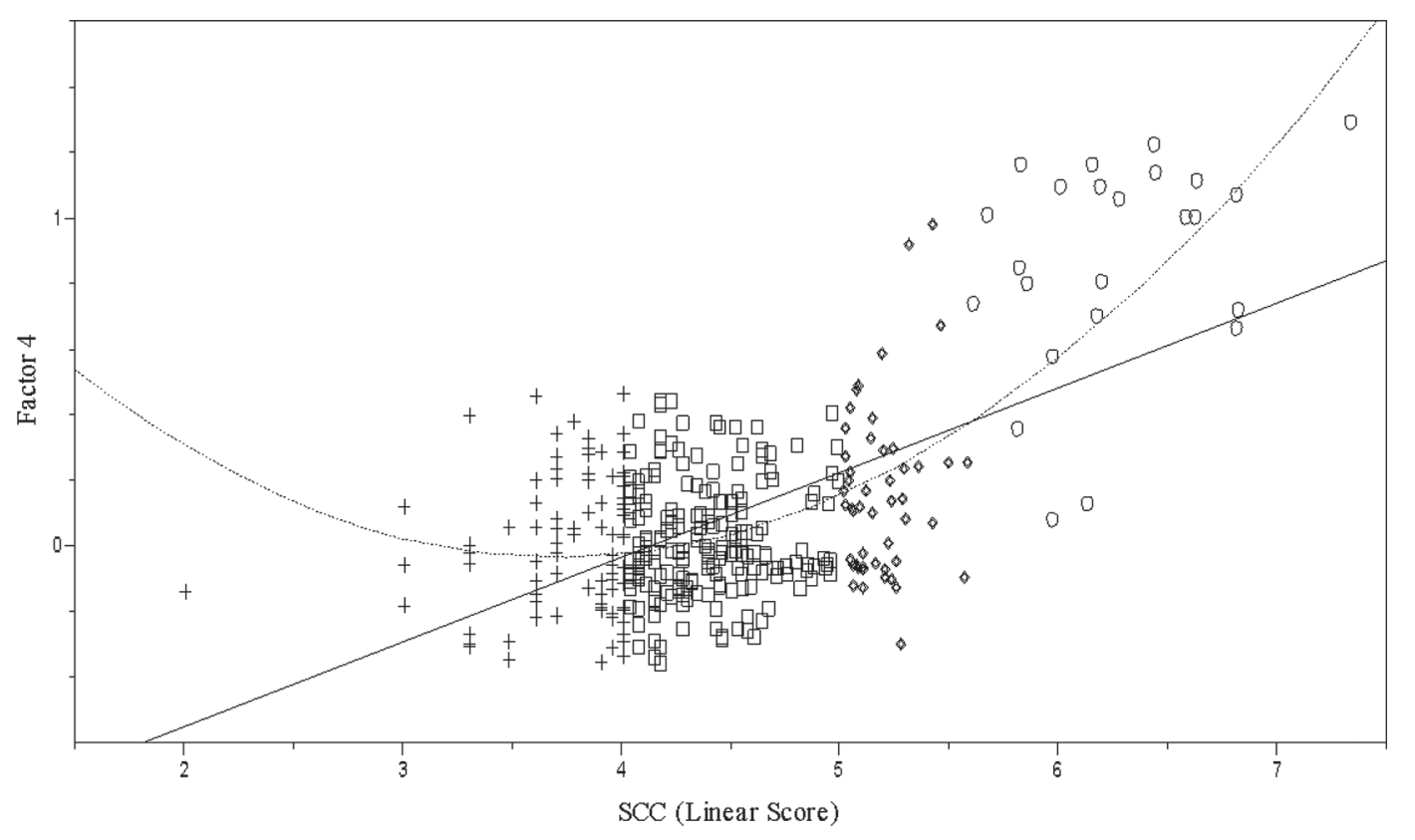

Figure 2. Relationship between SCC values (expressed as linear score) and scores of factor 4 . Continuous line $=$ linear effect $(\mathrm{y}=0.26 \mathrm{x}-$ $\left.1.06 ; \mathrm{R}^{2}=0.37 ; P<0.001\right)$; dashed line $=$ quadratic effect $\left(\mathrm{y}=0.12 \mathrm{x}^{2}+0.17 \mathrm{x}-0.75 ; \mathrm{R}^{2}=0.48 ; P<0.001\right) ;(+)$ quarters with SCC $<10,000$ cells/mL; $(\square)$ quarters with $10,000<\mathrm{SCC} \leq 100,000$ cells $/ \mathrm{mL} ;(\diamond)$ quarters with $100,000<\mathrm{SCC}<400,000$ cells $/ \mathrm{mL} ;(\bigcirc)$ quarters with SCC $>400,000$ cells $/ \mathrm{mL}$. 

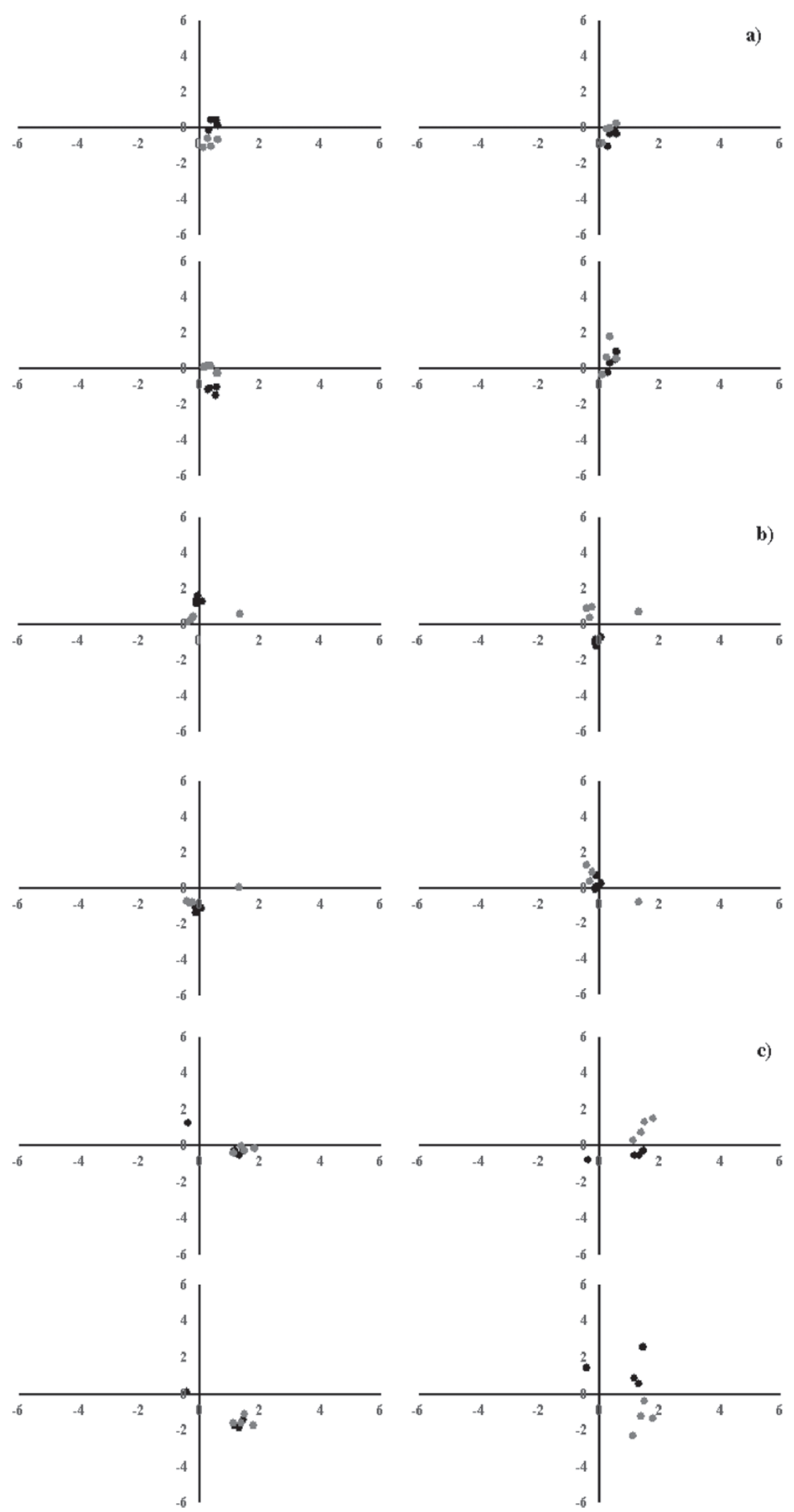

Figure 3. Example of the 3 cases observed for arranging the scores on a system of Cartesian axes: (a) all quarters with a similar metabolic pathway; (b) 1 of the 4 quarters with higher scores for the de novo synthesis factor than the other ones; (c) 1 quarter that showed a lower score for factor 1 . For each figure: factor $1 \times$ factor 2 (graph in the top left corner), factor $1 \times$ factor 3 (graph in the top right corner), factor $1 \times$ factor 4 (graph in the bottom left corner), and factor $1 \times$ factor 5 (graph in the bottom right corner). Gray dots $=$ quarter of the first sampling; black dots $=$ quarter of the second sampling. 
the situation may also result in a transient increase in SCC (Klastrup et al., 1987; Harmon, 1994). However, these fluctuations can be considered as systemic and occur in all 4 quarters simultaneously, thereby causing a temporarily different normal base level in all the udder quarters.

Our results demonstrated that de novo mammary FA synthesis was also significantly associated with changes in SCC values. The maximum potential of de novo mammary synthesis of milk FA seemed to be associated with a very low level of SCC $(<10,000)$. On the other hand, values between 10,000 and 100,000, which are usually considered as an indicator of a healthy udder, were associated with a slight but significant decrease in de novo FA synthesis.

\section{CONCLUSIONS}

Multivariate factor analysis enabled us to find an interesting interpretation key to milk FA composition as affected by milk SCC. Our statistical approach separated milk FA into groups with a common origin and function related to different aspects of lipid metabolism. By applying the ANOVA to the factor scores, a significant effect of the SCC class was detected. Positive scores of factor 1 were associated with very low levels of milk SCC $(<10,000)$. In addition, the higher the value of the SCC, the more negative the value of factor 1 scores. This relationship enabled us to differentiate between a single quarter with different SCC and the other quarters of the same udder. Because factor 1 included milk FA de novo synthesized by the mammary gland, our results suggest that the mammary efficiency in the neosynthesis of milk FA is probably already affected by SCC levels that are usually considered for healthy udders (from 10,000 to 100,000 cells). In fact, the highest scores of de novo milk FA factor were associated with very low levels of milk SCC $(<10,000$ cells $)$.

\section{ACKNOWLEDGMENTS}

This research was supported from the funds provided by the Centro di ricerche Agro-ambientali "E. Avanzi." The authors have not stated any conflicts of interest.

\section{REFERENCES}

Allore, H. G., D. J. Wilson, H. N. Erb, and P. A. Oltenacu. 1998. Selecting linear-score distributions for modelling milk-cultures results. Prev. Vet. Med. 33:11-29. https://doi.org/10.1016/S0167 -5877(97)00066-4.

Barkema, H. W., Y. H. Schukken, T. J. G. M. Lam, D. T. Galligan, M. L. Beiboer, and A. Brand. 1997. Estimation of interdependence among quarters of the bovine udder with subclinical mastitis and implications for analysis. J. Dairy Sci. 80:1592-1599. https://doi .org/10.3168/jds.S0022-0302(97)76089-2.

Bauman, D., and J. Griinari. 2001. Regulation and nutritional manipulation of milk fat: Low-fat milk syndrome. Livest. Prod. Sci. 70:15-29. https://doi.org/10.1016/S0301-6226(01)00195-6.

Berglund, I., G. Pettersson, K. Svennersten-Sjaunja, and K. Ostensson. 2004. Frequency of individual udder quarters with elevated CMT scores in cow's milk samples with low somatic cell counts. Vet. Rec. 155:213. https://doi.org/10.1136/vr.155.7.213.

Berglund, I., G. Pettersson, and K. Svennersten-Sjaunja. 2002. Automatic milking: Effects on somatic cell count and teat end-quality. Livest. Prod. Sci. 78:115-124. https://doi.org/10.1016/S0301 $-6226(02) 00090-8$

Bionaz, M., S. Chen, M. J. Khan, and J. J. Loor. 2013. Functional role of PPARs in ruminants: Potential targets for fine-tuning metabolism during growth and lactation. PPAR Res. 2013:1-28. https:// doi.org/10.1155/2013/684159.

Bionaz, M., and J. J. Loor. 2008. Gene networks driving bovine milk synthesis during the lactation cycle. BMC Genomics 9:366-387.

Cecchinato, A., N. P. P. Macciotta, M. Mele, F. Tagliapietra, S. Schiavon, G. Bittante, and S. Pegolo. 2019. Genetic and genomic analyses of latent variables related to the milk fatty acid profile, milk composition, and udder health in dairy cattle. J. Dairy Sci. 102:5254-5265. https://doi.org/10.3168/jds.2018-15867.

Cerny, B. A., and H. F. Kaiser. 1977. A study of a measure of sampling adequacy for factor analytic correlation matrices. Multivariate Behav. Res. 12:43-47. https://doi.org/10.1207/s15327906mbr1201_3.

Chilliard, Y., A. Ferlay, and M. Doreau. 2001. Effect of different types of forages animal fat or marine oils in cow's diet on milk fat secretion and composition especially conjugated linoleic acid (CLA) and polyunsaturated fatty acids. Livest. Prod. Sci. 70:31-48. https: //doi.org/10.1016/S0301-6226(01)00196-8.

Chilliard, Y., F. Glasser, A. Ferlay, L. Bernard, J. Rouel, and M. Doreau. 2007. Diet, rumen biohydrogenation and nutritional quality of cow and goat milk fat. Eur. J. Lipid Sci. Technol. 109:828855. https://doi.org/10.1002/ejlt.200700080.

Chilliard, Y., P. G. Toral, K. J. Shingfield, J. Rouel, C. Leroux, and L. Bernard. 2014. Effects of diet and physiological factors on milk fat synthesis, milk fat composition and lipolysis in the goat: A short review. Small Rumin. Res. 122:31-37. https://doi.org/10.1016/j .smallrumres.2014.07.014.

Conte, G., A. Serra, P. Cremonesi, S. Chessa, B. Castiglioni, A. Cappucci, E. Bulleri, and M. Mele. 2016. Investigating mutual relationship among milk fatty acids by multivariate factor analysis in dairy cows. Livest. Sci. 188:124-132. https://doi.org/10.1016/j .livsci.2016.04.018.

Conte, G., A. Serra, and M. Mele. 2017. Dairy cow breeding and feeding on the milk fatty acid pattern. Pages 19-41 in Nutrients in Dairy and Their Implications for Health and Disease. R. R. Watson, R. J. Collier, and V. R. Preedy, ed. Academic Press, London, United Kingdom.

Cunha, R. P. L., L. R. Molina, A. U. Carvalho, E. J. Facury Filho, P. M. Ferreira, and M. B. Gentilini. 2008. Subclinical mastitis and relationship between somatic cell count with number of lactations, production and chemical composition of milk. Arq. Bras. Med. Vet. Zootec. 60:19-24. https://doi.org/10.1590/S0102 $-09352008000100003$.

Dadousis, C., S. Pegolo, G. J. M. Rosa, G. Bittante, and A. Cecchinato. 2017. Genome-wide association and pathway-based analysis using latent variables related to milk protein composition and cheesemaking traits in dairy cattle. J. Dairy Sci. 100:9085-9102. https://doi.org/10.3168/jds.2017-13219.

Dann, H. M., D. E. Morin, G. A. Bollero, M. R. Murphy, and J. K. Drackley. 2005. Prepartum intake, postpartum induction of ketosis, and periparturient disorders affect the metabolic status of dairy cows. J. Dairy Sci. 88:3249-3264. https://doi.org/10.3168/ jds.S0022-0302(05)73008-3.

Dobranié, V., B. Njari, M. Samardžija, B. Mioković, and R. Resanović. 2008. The influence of the season on the chemical composition 
and the somatic cell count of bulk tank cow's milk. Vet. Arh. 78:235-242.

Douglas, G. N., J. Rehage, A. D. Beaulieu, A. O. Bahaa, and J. K. Drackley. 2007. Prepartum nutrition alters fatty acid composition in plasma, adipose tissue, and liver lipids of periparturient dairy cows. J. Dairy Sci. 90:2941-2959. https://doi.org/10.3168/jds.2006 -225 .

Enjalbert, F., M.-C. Nicot, C. Bayourthe, and R. Mouncoulon. 1998. Duodenal infusions of palmitic, stearic, or oleic acids differently affect mammary gland metabolism of fatty acids in lactating dairy cows. J. Nutr. 128:1525-1532. https://doi.org/10.1093/jn/128.9 .1525 .

Fievez, V., B. Vlaeminck, M. S. Dhanoa, and R. J. Dewhurst. 2003. Use of principal component analysis to investigate the origin of heptadecenoic and conjugated linoleic acids in milk. J. Dairy Sci. 86:4047-4053. https://doi.org/10.3168/jds.S0022-0302(03)74016 -8 .

Forsbäck, L., H. Lindmark-Månsson, A. Andrén, M. Åkerstedt, and K. Svennersten-Sjaunja. 2009. Udder quarter milk composition at different levels of somatic cell count in cow composite milk. Animal 3:710-717. https://doi.org/10.1017/S1751731109004042.

Gaspardo, B., A. Lavrenčič, A. Levart, S. Del Zotto, and B. Stefanon. 2010. Use of milk fatty acids composition to discriminate area of origin of bulk milk. J. Dairy Sci. 93:3417-3426. https://doi.org/10 $.3168 /$ jds.2009-2788.

Halasa, T., K. Huijps, O. Osteras, and H. Hogeveen. 2007. Economic effects of bovine mastitis and mastitis management. Vet. Q. 29:18 31. https://doi.org/10.1080/01652176.2007.9695224.

Hamann, J. 2002. Relationships between somatic cell count and milk composition. Bull. Int. Dairy Fed. 372:56-59.

Hamann, J. 2003. Definition of the physiological cell count threshold based on changes in milk composition. Bull. Int. Dairy Fed. 381:9-12.

Harmon, R. J. 1994. Physiology of mastitis and factors affecting somatic cell counts. J. Dairy Sci. 77:2103-2112. https://doi.org/10 .3168/jds.S0022-0302(94)77153-8.

Jensen, R. G. 2002. The composition of bovine milk lipids: January 1995 to December 2000. J. Dairy Sci. 85:295-350. https://doi.org/ 10.3168/jds.S0022-0302(02)74079-4.

Jensen, R. G., B. Blanc, and S. Patton. 1995. Particulate constituents in human and bovine milks. Pages 50-62 in Handbook of Milk Composition. R. G. Jensen, ed. Academic Press, San Diego, CA.

Jombart, T., D. Pontier, and A. B. Dufour. 2009. Genetic markers in the playground of multivariate analysis. Heredity 102:330-341. https://doi.org/10.1038/hdy.2008.130.

Kadegowda, A. K. G., M. Bionaz, L. S. Piperova, R. A. Erdman, and J. J. Loor. 2009. Peroxisome proliferator-activated receptorgamma activation and long-chain fatty acids alter lipogenic gene networks in bovine mammary epithelial cells to various extents. J. Dairy Sci. 92:4276-4289. https://doi.org/10.3168/jds.2008-1932.

Kay, J. K., W. J. Weber, C. E. Moore, D. E. Bauman, L. B. Hansen, H. Chester-Jones, B. A. Crooker, and L. H. Baumgard. 2005. Effects of week of lactation and genetic selection for milk yield on milk fatty acid composition in Holstein cows. J. Dairy Sci. 88:3886-3893. https://doi.org/10.3168/jds.S0022-0302(05)73074-5.

Klastrup, O., G. Bakken, J. Bramley, and R. Bushnell. 1987. Environmental influences on bovine mastitis. Bull. Int. Dairy Fed. $217: 2-37$

Kramer, J. K. G., M. Hernandez, C. Cruz-Hernandez, J. Kraft, and M. E. R. Dugan. 2008. Combining results of two GC separations partly achieves determination of all cis and trans 16:1, 18:1, 18:2 and 18:3 except CLA isomers of milk fat as demonstrated using Ag-Ion SPE fractionation. Lipids 43:259-273. https://doi.org/10 .1007/s11745-007-3143-4.

Leitner, G., N. Silanikove, S. Jacobi, L. Weisblit, S. Bernstein, and U. Merin. 2008. The influence of storage on the farm and in dairy silos on milk quality for cheese production. Int. Dairy J. 18:109-113. https://doi.org/10.1016/j.idairyj.2007.09.001.

Linzell, J. L., and M. Peaker. 1972. Day-to-day variations in milk composition in the goat and cow as a guide to the detection of subclinical mastitis. Br. Vet. J. 128:284-295. https://doi.org/10 .1016/S0007-1935(17)36932-4

Loften, J. R., J. G. Linn, J. K. Drackley, T. C. Jenkins, C. G. Soderholm, and A. F. Kertz. 2014. Invited review: Palmitic and stearic acid metabolism in lactating dairy cows. J. Dairy Sci. 97:46614674. https://doi.org/10.3168/jds.2014-7919.

Macciotta, N. P. P., A. Cecchinato, M. Mele, and G. Bittante. 2012. Use of multivariate factor analysis to define new indicator variables for milk composition and coagulation properties in Brown Swiss cows. J. Dairy Sci. 95:7346-7354. https://doi.org/10.3168/ jds.2012-5546.

Macciotta, N. P. P., C. Dimauro, D. J. Null, G. Gaspa, M. Cellesi, and J. B. Cole. 2015. Dissection of genomic correlation matrices of US Holsteins using multivariate factor analysis. J. Anim. Breed. Genet. 132:9-20. https://doi.org/10.1111/jbg.12113.

Macciotta, N. P. P., D. Vicario, C. Dimauro, and A. Cappio-Borlino. 2004. A multivariate approach to modelling shapes of individual lactation curves in cattle. J. Dairy Sci. 87:1092-1098. https://doi .org/10.3168/jds.S0022-0302(04)73255-5.

Malek dos Reis, C. B. J. R. Barreiro, L. Mestieri, M. A. F. Porcionato, and M. V. dos Santos. 2013. Effect of somatic cell count and mastitis pathogens on milk composition in Gyr cows. BMC Vet. Res. 9:67. https://doi.org/10.1186/1746-6148-9-67.

McDonald, R. P. 1985. Factor Analysis and Related Methods. Erlbaum Associates Publishers, Hillsdale, Mahwah, NJ.

Mele, M., G. Conte, B. Castiglioni, S. Chessa, N. P. P. Macciotta, A. Serra, A. Buccioni, G. Pagnacco, and P. Secchiari. 2007. StearoylCoA desaturase gene polymorphism and milk fatty acid composition in Italian Holsteins. J. Dairy Sci. 90:4458-4465. https://doi .org/10.3168/jds.2006-617.

Mele, M., R. Dal Zotto, M. Cassandro, G. Conte, A. Serra, A. Buccioni, G. Bittante, and P. Secchiari. 2009. Genetic parameters for conjugated linoleic acid, selected milk fatty acids, and milk fatty acid unsaturation of Italian Holstein-Friesian cows. J. Dairy Sci. 92:392-400. https://doi.org/10.3168/jds.2008-1445.

Mele, M., N. P. P. Macciotta, A. Cecchinato, G. Conte, S. Schiavon, and G. Bittante. 2016. Multivariate factor analysis of detailed milk fatty acid profile: Effects of dairy system, feeding, herd, parity, and stage of lactation. J. Dairy Sci. 99:9820-9833. https://doi.org/10 .3168/jds.2016-11451.

Merle, R., A. Schröder, and J. Hamann. 2007. Cell function in the bovine mammary gland: A preliminary study on interdependence of healthy and infected udder quarters. J. Dairy Res. 74:174-179. https://doi.org/10.1017/S002202990600238X.

Morrison, F. 1976. Multivariate Statistical Methods. McGraw-Hill, New York, NY.

Nickerson, S. C., and R. M. Akers. 2011. Mammary gland. Pages 328337 in Encyclopedia of Dairy Sciences, 2nd ed., Vol. 3. Academic Press, Cambridge, MA.

Paape, M. J., D. D. Bannerman, X. Zhao, and J. W. Lee. 2003. The bovine neutrophil: Structure and function in blood and milk. Vet. Res. 34:597-627.

Paape, M. J., J. Mehrzad, X. Zhao, J. Detilleux, and C. Burvenich. 2002. Defense of the bovine mammary gland by polymorphonuclear neutrophil leukocytes. J. Mammary Gland Biol. Neoplasia $7: 109-121$.

Palmquist, D. L., A. D. Beaulieu, and D. M. Barbano. 1993. Feed and animal factors influencing milk fat composition. J. Dairy Sci. 76:1753-1771. https://doi.org/10.3168/jds.S0022-0302(93)77508 -6 .

Santos, M. V., Y. Ma, and D. M. Barbano. 2003. Effect to somatic cell count on proteolysis and lipolysis in pasteurized fluid milk during shelf-life storage. J. Dairy Sci. 86:2491-2503. https://doi.org/10 .3168/jds.S0022-0302(03)73843-0.

Schwarz, D., U. S. Diesterbeck, K. Failing, S. König, K. Brügemann, M. Zschöck, W. Wolter, and C. P. Czerny. 2010. Somatic cell counts and bacteriological status in quarter foremilk samples of cows in Hesse, Germany-A longitudinal study. J. Dairy Sci. 93:5716-5728. https://doi.org/10.3168/jds.2010-3223. 
Sjaunja, L. O. 1986. Day-to-day variation in milk yield, milk composition and somatic cell count. International Committee for Recording of the Productivity of Milk Animals (ICRPMA). 25th Session.

Stoop, W. M., H. Bovenhuis, J. M. L. Heck, and A. M. van Arendonk. 2009. Effect of lactation stage and energy status on milk fat composition of Holstein-Friesian cows. J. Dairy Sci. 92:1469-1478. https://doi.org/10.3168/jds.2008-1468.

Stoop, W. M., J. A. M. Van Arendonk, J. M. L. Heck, H. J. F. van Valenberg, and H. Bovenhuis. 2008. Genetic parameters for major milk fatty acids and milk production traits of Dutch HolsteinFriesians. J. Dairy Sci. 91:385-394. https://doi.org/10.3168/jds .2007-0181.

Toral, P. G., Y. Chilliard, J. Rouel, H. Leskinen, K. J. Shingfield, and L. Bernard. 2015. Comparison of the nutritional regulation of milk fat secretion and composition in cows and goats. J. Dairy Sci. 98:7277-7297. https://doi.org/10.3168/jds.2015-9649.

Vangroenweghe, F., H. Dosogne, and C. Burvenich. 2002. Composition and milk cell characteristics in quarter milk fractions of dairy cows with low cell count. Vet. J. 164:254-260. https://doi.org/10.1053/ tvjl.2002.0725.
Vlaeminck, B., V. Fievez, A. R. J. Cabrita, A. J. M. Fonseca, and R. J. Dewhurst. 2006. Factors affecting odd- and branched-chain fatty acids in milk: A review. Anim. Feed Sci. Technol. 131:389-417. https://doi.org/10.1016/j.anifeedsci.2006.06.017.

Zecconi, A., D. Vairani, M. Cipolla, N. Rizzi, and L. Zanini. 2019. Assessment of subclinical mastitis diagnostic accuracy by differential cell count in individual cow milk. Ital. J. Anim. Sci. 18:460-465. https://doi.org/10.1080/1828051X.2018.1533391.

\section{ORCIDS}

L. Turini (®) https://orcid.org/0000-0002-4164-8263

G. Conte $\odot$ https://orcid.org/0000-0002-7257-4762

F. Bonelli (๖ https://orcid.org/0000-0002-4119-7781

A. Serra (ㄴ) https://orcid.org/0000-0001-7728-3430

M. Sgorbini (i) https://orcid.org/0000-0002-0294-1803

M. Mele (ㄴ) https://orcid.org/0000-0002-7896-012X 